\title{
STUDENTS' ATTITUDES AND PERCEPTIONS TOWARDS MATHEMATICS: THE CASE OF SECONDARY SCHOOLS IN BORANA ZONE, ETHIOPIA
}

\author{
Awol Assen \\ Wollo University, Welo, Dessie, Ethiopia \\ E-mail: hassenawol@gmail.com
}

\begin{abstract}
Abstrak
Matematika adalah bidang ilmu penting yang diterapkan di hampir semua bidang pengetahuan dan kehidupan sehari-hari individu. Oleh karena itu, memahami sikap siswa terhadapnya dan faktor yang mempengaruhi prestasi mereka dalam matematika merupakan langkah penting untuk intervensi yang tepat agar pelajaran matematika menjadi menyenangkan. Artikel ini bertujuan untuk memberikan gambaran yang komprehensif tentang sikap siswa terhadap matematika dan faktor-faktor yang mempengaruhi sikap dan prestasi mereka. Untuk mencapai tujuan tersebut digunakan teknik purposive dan random sampling. Kuesioner yang mengukur sikap dan prestasi siswa dalam mata pelajaran tersebut dibagikan kepada sampel siswa di sekolah menengah. Pengumpulan data dilakukan dengan menggunakan kuesioner yang divalidasi, diujicobakan, dan ditentukan reliabilitasnya. Analisis data menggunakan statistik deskriptif. Siswa diminta untuk menanggapi kuesioner skala Likert dengan 5 poin yang mencakup faktor-faktor yang mempengaruhi praktik mengajar, atribusi guru, iklim kelas, dan perhatian siswa sebagai faktor yang berkontribusi terhadap sikap mereka terhadap matematika. Selain itu, lima pertanyaan jawaban bebas juga dimasukkan untuk mendapatkan gambaran mendalam siswa tentang matematika. Hasil penelitian menunjukkan bahwa siswa memiliki sikap yang hampir positif terhadap matematika. Faktor-faktor yang berkontribusi terhadap kinerja yang buruk termasuk kurangnya latihan, kekurangan bahasa, pengaruh sosial, isi mata pelajaran yang luas, kurangnya latar belakang kursus, cara pengembangan ujian matematika, tidak adanya tutorial, kebutuhan untuk lebih banyak rekreasi, dan kurangnya keyakinan. Sikap siswa terhadap matematika telah menentukan prestasi siswa secara langsung serta sikap siswa dan pencapaiannya saling bergantung.
\end{abstract}

Kata Kunci: Sekolah Menengah Pertama, Sikap Siswa, Prestasi, Faktor yang Mempengaruhi, Matematika

\begin{abstract}
Mathematics is an essential field of science applied in nearly all areas of knowledge and individuals' daily lives. Therefore, understanding students' attitudes towards it and affecting their mathematics performance is an essential step for appropriate intervention to make the subject enjoyable. This paper aims to give a comprehensive picture of students' attitudes towards mathematics and factors that affect their attitude and achievement. To achieve this objective, purposive and random sampling techniques were used. A questionnaire measuring students' attitudes and their achievement in the subject was distributed to sample students in secondary schools. Data were collected using a questionnaire that was validated, pilot tested, and its reliability was determined. The data were analyzed using descriptive statistics. Students were asked to respond to a 5-point Likert scale questionnaire that includes factors that affect the teaching practice, teachers' attribution, classroom climate, and students' concern as a contributing factor for their attitude towards mathematics. Besides, five free-response questions were also
\end{abstract}


included to get an in-depth view of students towards mathematics. Results indicated that students have an almost positive attitude towards mathematics. Factors contributing to poor performance include lack of practice, language deficiency, societal influence, comprehensive content of the subject, lack of background on the course, development of examination in mathematics, absence of tutorial, the need for more recreation, and lack of confidence. Students' attitude towards mathematics has determined students' achievement directly as well as the perspective of students, and their achievements are interdependent.

Keywords: Secondary school, Students'attitude, Achievement, Influencing factors, Mathematics

\section{INTRODUCTION}

Mathematics is recognized worldwide as the most important subject in most fields of human endeavors. Its usefulness in science, technological activities, commerce, economics, education and even humanities is almost at par with the importance of education as a whole (Tella, 2017; White, 2019). Mathematics plays a role in students' life all over the world by serving as a bridge to science, technology and other subjects offered in any formal educational system (Standslause, Maito, \& Ochiel, 2013; Bergsten \& Frejd, 2019).

Ethiopia has recently designed a strategy through which $70 \%$ of the enrollment in the universities should be in science and technology (Demssie, 2019). This strategy has still been implemented that creates a strong students' attention for science courses, particularly mathematics. In order to achieve this vision of our country, a study on secondary school students' attitudes and achievement in mathematics is necessary because one's attitude affects the interpretation, evaluation, disposition or view towards mathematics. Attitude is a central part of human identity. Everyday people love, hate, like, dislike, favour, oppose, agree, disagree, argue, persuade, etc. Hence, attitudes can be defined as a summary evaluation of an object of thought (Bohner \& Wänke, 2002). It is common to heard from the students that "I like/dislike Mathematics" or "Mathematics is boring, difficult, etc." subject, which are aspects of attitude.

An attitude is a point of view about a situation; it is a way of thinking. It is an inward feeling expressed by outward behavior. It has implications for the learner, the teacher, the social group with which the individual learner relates. Attitudes are formed as a result of some kind of learning experiences (Standslause et al., 2013). Attitudes influence performance, then performance in turn influences attitudes (Sarwat, Safia, \& Manzoor, 2013). Ajayi, Lawani, and Adeyanju (2011) stated that the end of the secondary school is 
the beginning of identification of potential and how far a student can go in pursuit of his/her academic career. The authors added that high percentage of secondary school students continue to perform poorly in mathematics examinations. This poor performance continues to generate much concern among parents, teachers, students and other stakeholder in the education business.

Previous studies revealed that students' performance in science \& mathematics is very low. It is also believed that failure in science and mathematics contributes to repeat class years and eventually leads to their dropping out (Eshetu, Dilamo, Tsfaye, \& Zinabu, 2009). They also added that mathematics education has had a bad reputation because many students do not like the subject and many students find it difficult. Thus, studying students' attitude and achievements at secondary level (grade $9^{\text {th }}$ and $10^{\text {th }}$ ) is very crucial as their future career depends on the academic successes achieved in science subjects, especially in mathematics. Even though there are similar studies in different secondary schools of Ethiopia (e.g. Engida \& Zeytu, 2017; Mekuria, Alemu, \& Tadesse, 2018; Agdie, Mekasha, Ali, Mamo, Mitiku, \& Gone, 2019), it is difficult to generalize the results to Borana secondary schools as they are situated in the marginal areas with poor infrastructure facilities and very different the socioeconomic environment. This study generally sought to investigate students' attitude towards learning mathematics and their achievements. The specific objectives were to examine students' attitude towards mathematics, asses factors affecting secondary school students' attitudes and achievement towards mathematics, and determine the effect of students' attitude on their performance in Mathematics.

\section{METHOD}

Borana zone is one of the zones from Oromia National Regional State, which has 13 woredas and 2 Municipal towns. During the time of data collection, the total number of secondary schools and students in Borana zone are 29 and 11,103 respectively. The target population comprised of five secondary school students namely Bule Hora (B), Finchawa (F), Yabello (Y), Melkasoda (Me) and Moyale (Mo) Secondary Schools.

Both primary and secondary data sources were used. The primary data were collected through observation, interview, focus group discussion (FGD) with twenty-five informants ( 5 informants from each school), and questionnaires consisted of both closed 
and open-ended items. The scale of five points Likert items has ranged from strongly agree (5) to strongly disagree (1). Secondary source of information were both published and unpublished materials.

The survey was conducted by ten trained teachers in the sample high schools. Initially, a pilot test was conducted on 50 students who were excluded in the main study and there by the questionnaires were further improved. For the main study, fifty sample students were purposively and randomly selected by considering gender \& grade level from each school. The total sample of the study consisted of 250 students who were selected from five secondary schools. However, only 200 questionnaires were correctly filled and returned.

The data collected were analyzed using both quantitative and qualitative methods. Qualitative data which were generated through secondary sources, interview, formal and informal discussion and observation was analyzed qualitatively. Quantitative data from close ended questionnaire were analyzed by using descriptive statistics. The completed questionnaires were sorted, classified and coded to analyze using Statistical Package for Social Science (SPSS version 20).

\section{RESULTS AND DISCUSSION}

\section{Students' attitude towards mathematics}

Figure 1 presented students' attitude towards mathematics. Students' attitude towards learning mathematics was generally found not a big problem in Borana zone secondary school students (grade 9 and 10). This was witnessed by the positive attitude of majority of the students as they disagreed and strongly disagreed to the negative statements which says 'mathematics is boring (69.3\%)', 'I'm good at many subjects except mathematics (65\%)', 'I think every student can't understand mathematics (58.8\%)', 'I feel sick during mathematics test (72.7\%)' and 'I don't want to know mathematics (79.5\%)'. However, considerable proportion of students $(>20 \%)$ also agreed and strongly agreed to some negative statements as illustrated in Figure 1, which could have a negative consequence if it continued unchanged. For instance, students who believe that they can't understand mathematics have little chance to study it in detail. Therefore, this attitude should be changed first to bring a good progress in mathematics. 


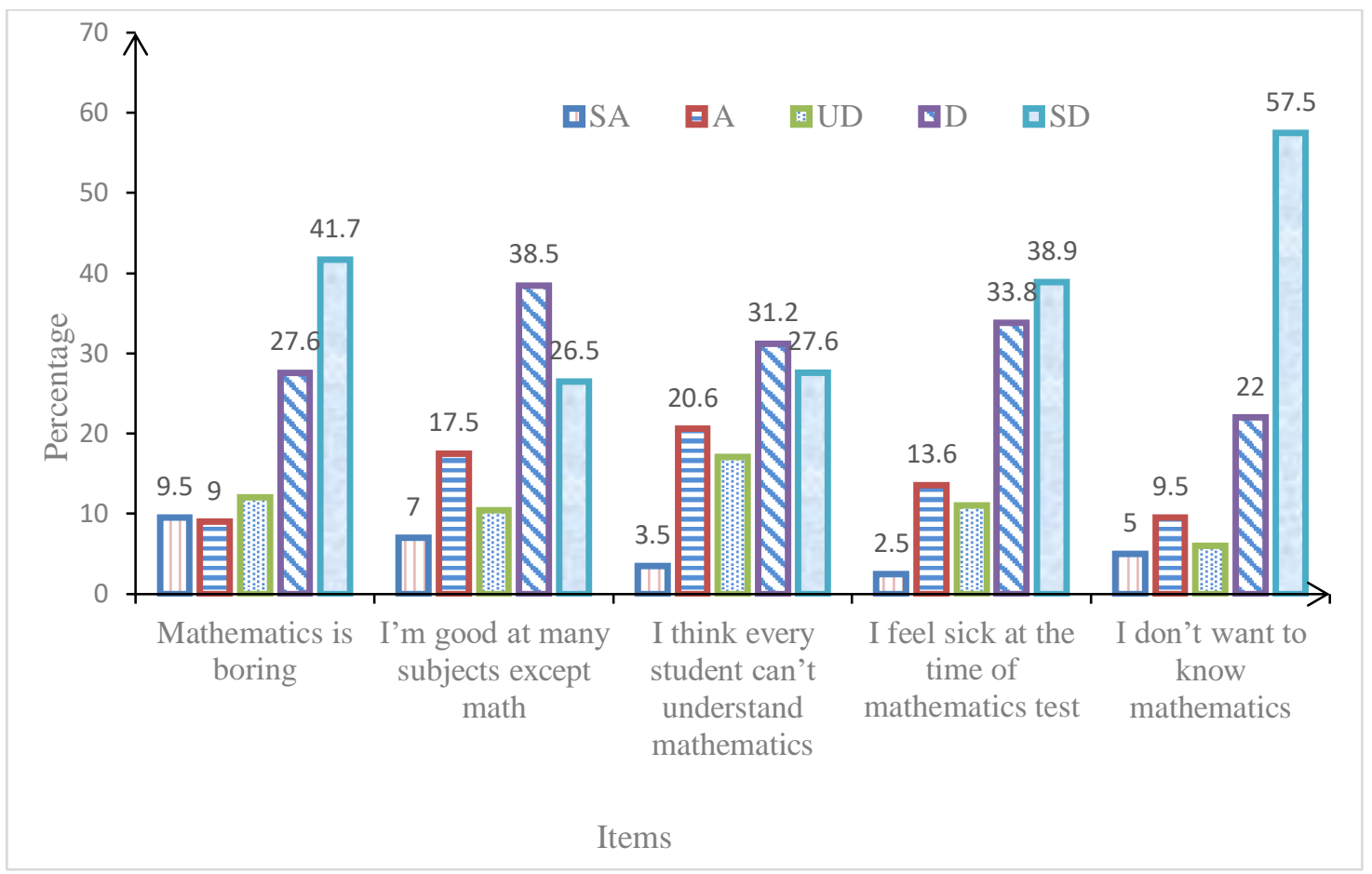

Figure 1. Percentage of students' responses on attitude towards mathematics ( $\mathrm{SA}=$ Strongly Agree, $\mathrm{A}=$ Agree, $\mathrm{UD}=$ Undecided, $\mathrm{D}=$ Disagree, $\mathrm{SD}=$ Strongly Disagree)

\section{The relationship between students'achievement and their attitude}

The sample students' score out of 100 in mathematics was collected from mathematics teacher in the respective schools and the mean score is summarized in Figure 2. It clearly demonstrated high interdependency between attitude of student towards mathematics and their achievements. The students having negative attitude achieved less score whereas those having a positive attitude have got a high score. This result agreed with the previous study in that poor attitude leads to poor achievement and poor achievement leads to lack of willingness to attend the subject (Olaosebika, 1985). Therefore, motivating students to improve their positive attitude towards mathematics through different ways such as demonstrating the easiest ways to best understand mathematics and its applications in most fields of human endeavors. 


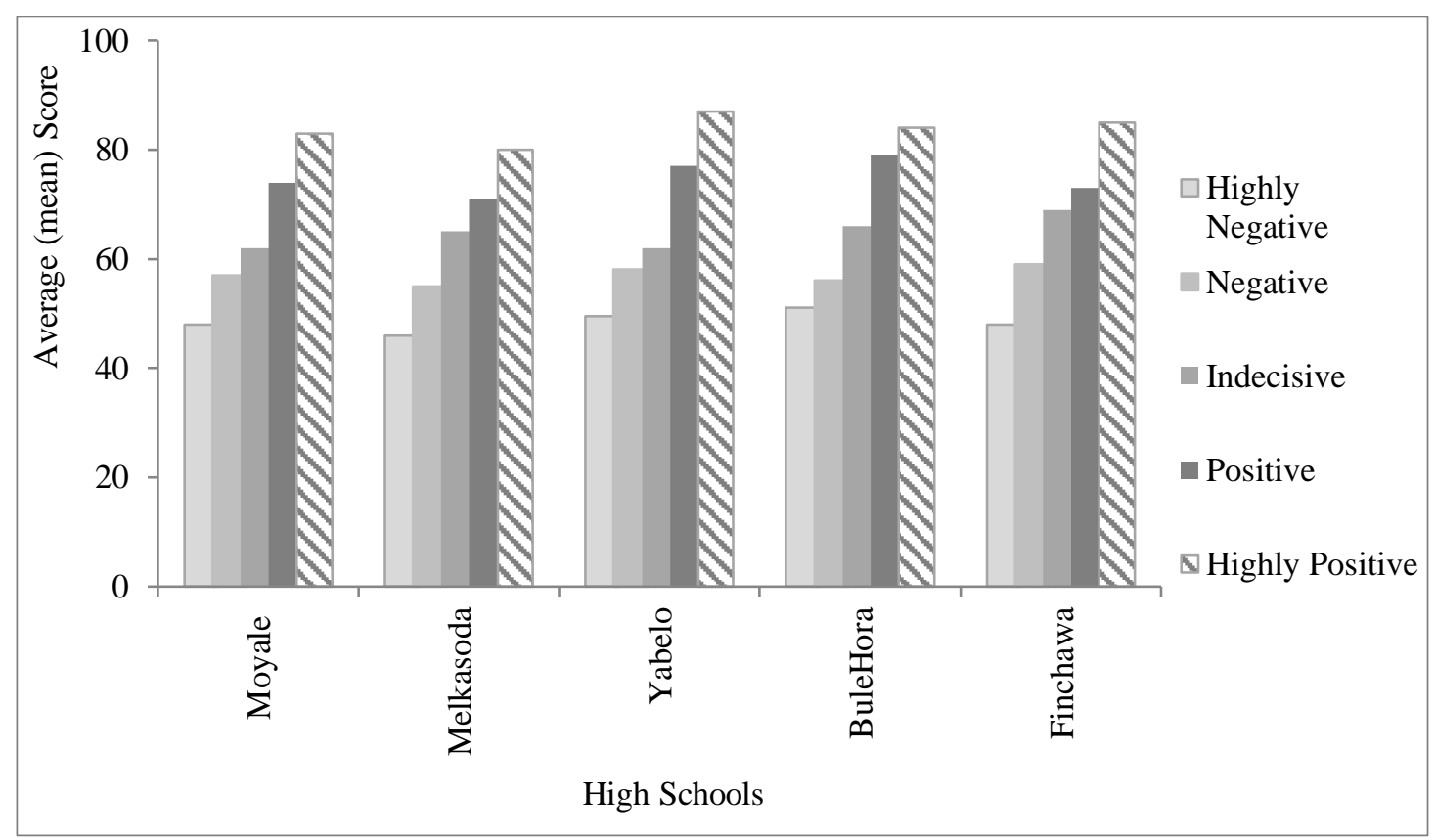

Figure 2. The Relation between students' achievement with their attitude

\section{Students' perception on the content of mathematics and teaching environment}

From students' Focus Group Discussion (FGD) and open-ended questionnaires, it was found that some teachers themselves express their negative attitudes towards mathematics, encouraging students to pursue higher levels of education in subjects other than mathematics. The students believed that good mathematics teacher is the one who teaches clearly, shows helpfulness to the students in/outside the class, make good preparation in advance, and provides exercises/exams that enables students to learn rather than to consider it as a challenge. They also added that some teachers were not good in their subject matter knowledge and this problem is especially magnified as mathematics syllabus is very wide to plan and finish it timely through decentralized teaching methods. As illustrated Figure 3, the majority of Borana secondary school students agreed that their teacher teaches well (43.0\%), efficient (32.5\%), attractive way of teaching mathematics $(33.3 \%)$ and they have made discussion among each other during mathematics class (37.2\%). Also, considerable proportion of students (27.7\%) were satisfied with most teachers' lecturing system. In general majority of respondents showed slightly positive perception on the Content of mathematics subject and teachers' methodology.

Lack of simulation that comes from lack of reference books and small class size will further causes a student to lose interest and get bored easily in their learning. In most 
of the school, however, majority of the respondents said that class room size and teaching materials were not a problem in affecting their attitude towards learning mathematics. On the contrary, most of the students in Finchawa secondary school and that of Melkasoda underlined that lack of reference books was a big problem. Besides, students also explained that some of the teachers used teaching aids but others didn't used.

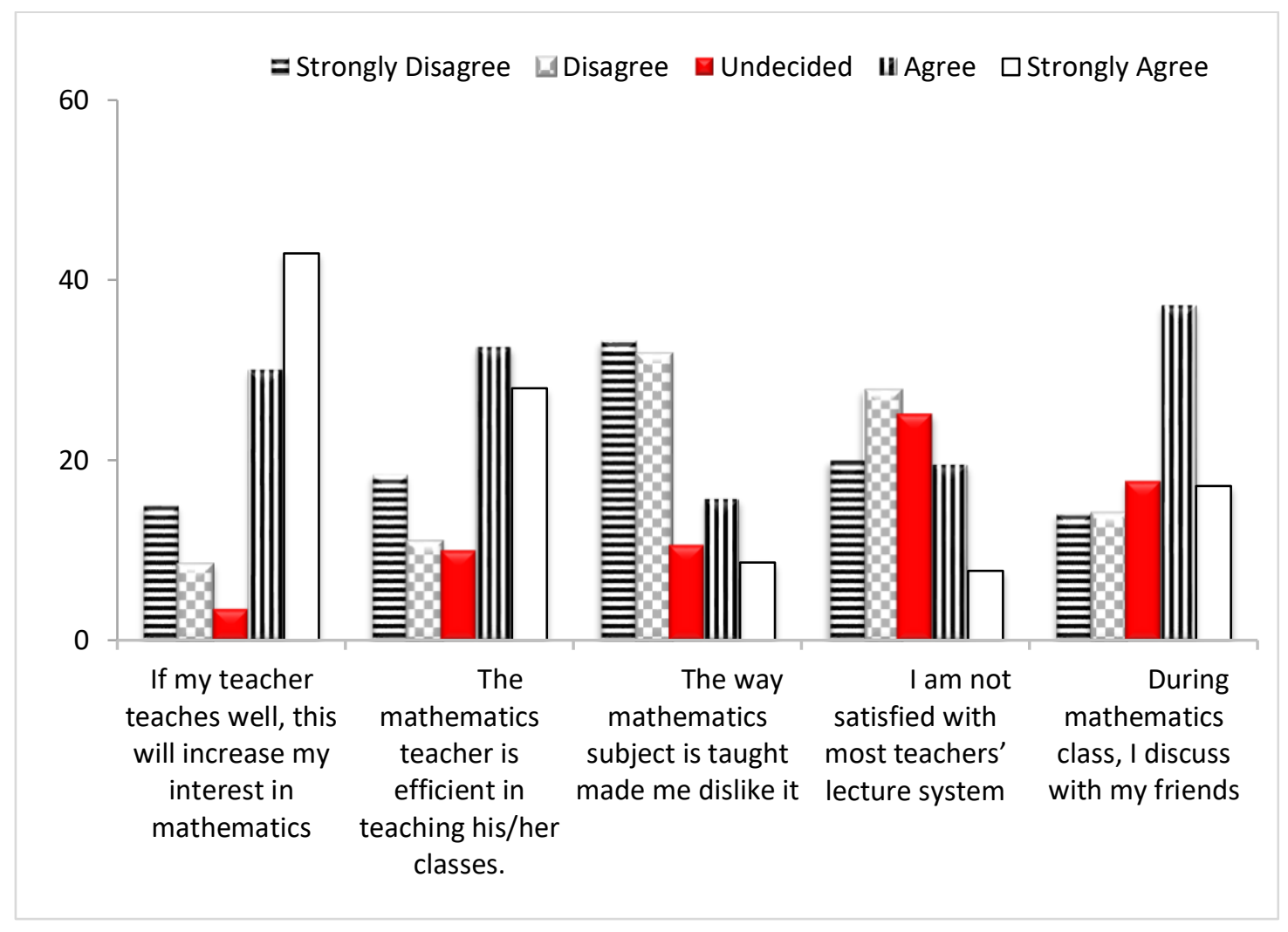

Figure 3. Responses of students on mathematics content and teaching environment

\section{Students'perception on the importance of mathematics}

As shown in Figure 4, Most of the respondents did not believe on the statements said 'mathematics skills will not help them to get a job ((57.1\%)', 'mathematics is not more important than other subjects (45.5\%),' and 'mathematics will be useless for their day to day activities $(50.8 \%)^{\prime}$. A relatively higher proportion of the students also believed that 'mathematics knowledge helps to learn other subject easily (29.9\%)' and 'knowing mathematics is important (37.1\%)'. Moreover, about one third of the students $(31.6 \%)$ were interested to work in the field of mathematics. Generally, most of respondents have a positive perception about the importance of mathematics and its application in their 
future life.

I believe that mathematics will be useless for my everyday life

Nowadays, knowing mathematics is important

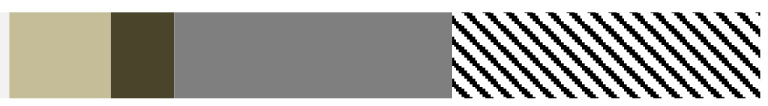

Mathematics is not more important than other subjects

Mathematics knowledge helps to learn other subject easily

I am interested in working in the field of mathematics in the future

Mathematics skills will not help me to get a job when I leave school
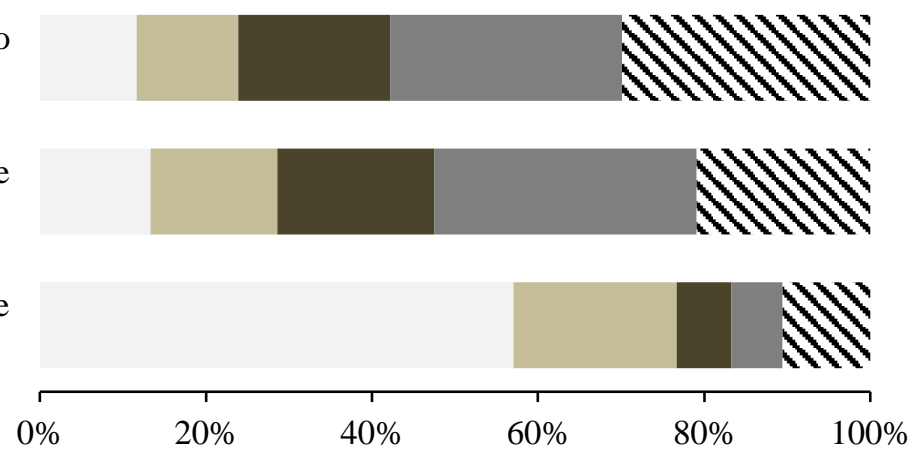

Strongly Disagree $\square$ Disagree $\quad$ Undecided $\quad$ Agree $\quad$ Strongly Agree

Figure 4. Percentage of students' response on the importance of Mathematics

\section{Factors affecting students' attitude and achievement}

Even though students have generally a positive attitude towards mathematics, the data obtained from open-ended questionnaires, interview, classroom observation and FGD pointed out several factors affecting their achievements (Figure 5). Lack of practice was one of the main factors. Students mentioned that they are good in the class while they were practicing, but achieved less score in their exam due to discontinuous exercise. Practice and drills are essentials for their learning too (Silva, Tadeo, Delos Reyes, \& Dadigan, 2006). Language deficiency was the other barrier. The students explained that they learn one English course as a second language but not enough to understand different vocabularies in mathematics, and some vocabularies are neither translatable nor giving the direct meanings. The students also added that even mathematics teachers cannot interpret confusing words in the mother tongue. Poor mathematics background, absence of tutorial and lack of confidence to solve problems were also mentioned during the interview. Furthermore, the type of exam item (multiple choice questions) mainly during 
Journal of Honai Math, Vol. 3, No. 2, pp. 169-180, Oktober 2020

Assen, Students 'Attitudes and Perceptions Towards Mathematics: The Case of Secondary Schools in Borana Zone, Ethiopia

final examination and model examination were mentioned as a big problem.
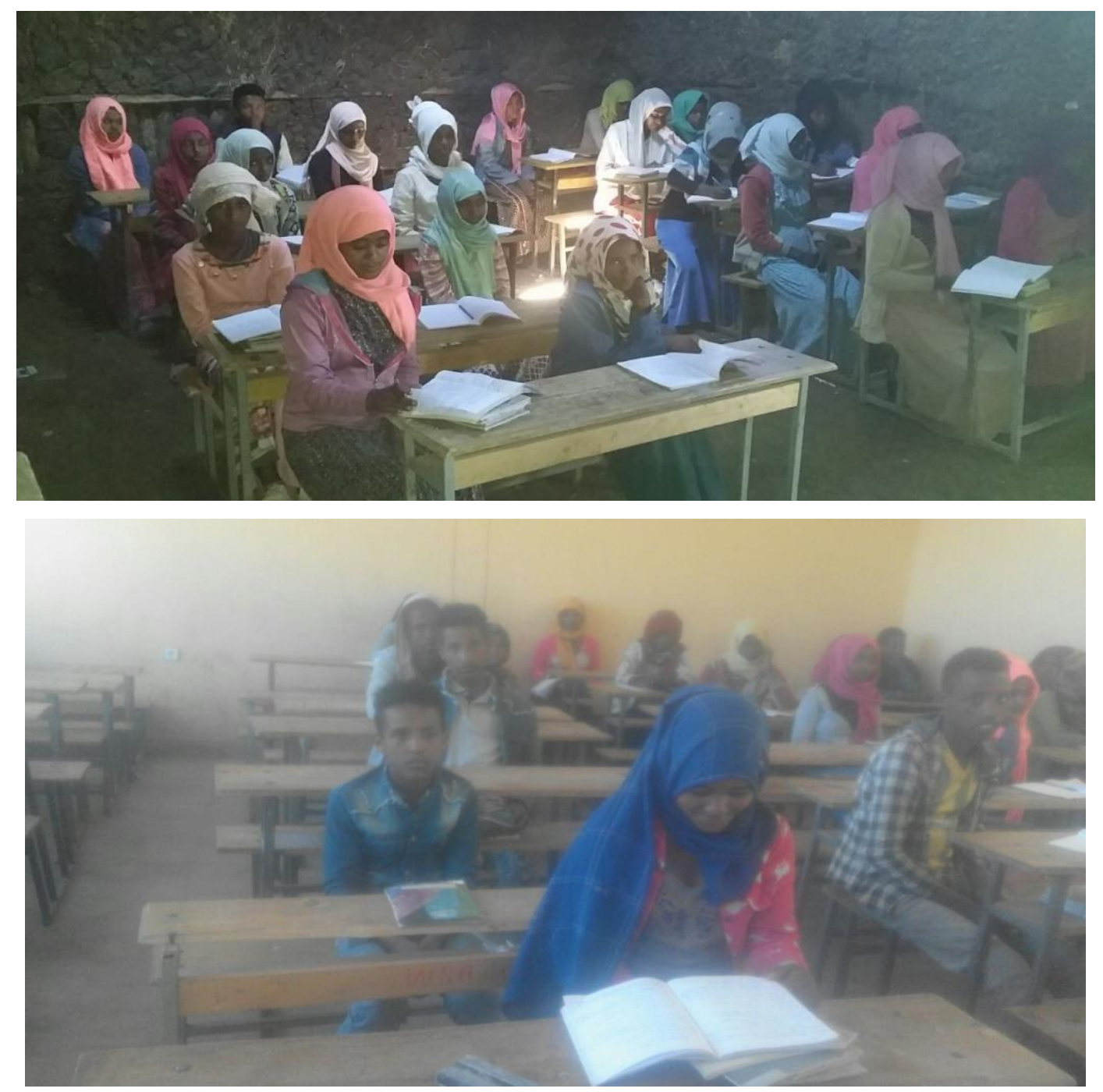

Figure 5. Classroom observation photos

Most interviewers mentioned that students have knowhow to solve mathematics problems but their problem is getting the correct answers and fast solution in multiple choice items. The need for more refreshment also negatively affected students to stay concentrated longer in practicing different mathematical problems. There were also social factors raised in FGD, which include absence of role model students, lack of parents' motivation and making students busy with different household activities, lack of academic support from their parents as most students belong to illiterate families as well as negative talks about mathematics from peers, parents, teachers and the society in 
general.

Even though students have positive attitude toward mathematics, there are factors which affect students' attitude and achievement such as lack of practice, lack of mathematics background (Silva et al., 2006), language deficiency (Githua, 2013), societal influence (Oundo \& Chuka, 2013; Zachariah, Komen, George, \& George, 2012), types of items in the examination, lack of tutorial, the need of more recreation and lack of confidence to solve problems (Engida \& Zeytu, 2017). The results of this study would have a great contribution for educational offices of the zone as well as ministry of education to see what is going on regarding students' attitude towards mathematics and thereby to make rational intervention.

\section{CONCLUSION}

This study highlights a number of important results that provide further information concerning the links between achievement in mathematics and attitudes towards mathematics. Students have slightly positive attitude towards mathematics. Students' attitude towards mathematics has predicted students' achievement directly and the attitude of students and their achievements were found interdependent each other. It will be also interesting to know the attitudes held by students in other grade levels especially at preparatory level and in universities.

\section{REFERENCES}

Agdie, T. G., Mekasha, M. T., Ali, A. B., Mamo, M., Mitiku, M., \& Gone, S. (2019). Assessment of Teachers' Attitude, Students' Attitude and Performance in Mathematics in Secondary Schools: A Case Study in Hawassa City and Hawassa Zuria Woredas, Ethiopia. American Journal of Theoretical and Applied Statistics, 8(3), 94-107.

Ajayi, K. O., Lawani, A. O., \& Adeyanju, H. I. (2011). Effects of students' attitude and self-concept on achievement in senior secondary school mathematics in Ogun State, Nigeria. Journal of research in national development, 9(2), 202-211.

Bergsten, C., \& Frejd, P. (2019). Preparing pre-service mathematics teachers for STEM education: an analysis of lesson proposals. ZDM, 51(6), 941-953.

Bohner, G., \& Wänke, M. (2002). Attitudes and Attitude Change. East Sussex: Psychology Press.

Demssie, M. (2019). Perceived factors affecting students' mathematics performance in 
North Showa Zone Secondary Schools in Ethiopia. International Journal of Advanced Research in Engineering and Applied Sciences, 8(5), 21-36.

Engida, M., \& Zeytu, G. (2017). Assessing the Influence of Attitude Towards Mathematics on Achievement of Grade 10 and 12 Female Students in Comparison with Their Male Counterparts: Wolkite, Ethiopia. International Journal of Secondary Education, 5(5), 56-69.

Eshetu, A., Dilamo, O., Tsfaye, A., \& Zinabu, G. (2009). Science and mathematics secondary education in Ethiopia. An Option paper presented at the Technical Workshop on Science and Mathematics Secondary Education in Africa (SEIA) Follow-up Program, Tunis.

Githua, B. N. (2013). Secondary school students' perceptions of mathematics formative evaluation and the perceptions' relationship to their motivation to learn the subject by gender in Nairobi and Rift Valley Provinces, Kenya. Asian Journal of Social Sciences and Humanities, 2(1), 174-183.

Mekuria, Y. S., Alemu, S. D., \& Tadesse, H. (2018). Analysis of Students' Commitment and Attitude towards Mathematics in Secondary School of Dega Woreda, Oromia National Regional State, Ethiopia. Humaniora, 9(2), 187-197.

Olaosebikan, F. (1985). Poor students' Performance in School Certificate Science Examination: Causes and Remedies. STAN 27th Conference Proceedings, 137-142.

Oundo, M. B., \& Chuka, K. (2013). Factors affecting mathematics academic counseling Services: the secondary school counsellors' perspective. International Journal of Education and Research, 1(12), 57-85.

Sarwat, M., Safia, S., \& Manzoor, H. A. (2013). Attitude towards Mathematics and Academic Achievement in Mathematics among Secondary Level Boys and Girls. IOSR Journal of Humanities and Social Science (JHSS), 6(4), 38-41.

Silva, D. L., Tadeo, M. C., Delos Reyes, V., \& Dadigan, R. M. (2006). Factors associated with non-performing Filipino students in mathematics: A vision of student's cognitive and behavior management. Proceedings of the $2^{\text {nd }}$ IMT-GT Regional conference on Mathematics, Statistics and Applications. Penang: Universiti Sains Malaysia.

Standslause, O. E., Maito, T. L., \& Ochiel, J. O. (2013). Teachers and students attitude towards mathematics in secondary schools in Siaya County, Kenya. Asian Journal of Management Sciences and Education, 2(3), 116-123.

Tella, A. (2017). Teacher variables as predictors of academic achievement of primary school pupils mathematics. International Electronic Journal of Elementary Education, 1(1), 16-33.

White, T. (2019). Artifacts, Agency and Classroom Activity: Materialist Perspectives on Mathematics Education Technology. Cognition and Instruction, 37(2), 169-200. 
Journal of Honai Math, Vol. 3, No. 2, pp. 169-180, Oktober 2020

Assen, Students'Attitudes and Perceptions Towards Mathematics: The Case of Secondary Schools in Borana Zone, Ethiopia

Zachariah, K. M., Komen, K., George, M. M., \& George, R. N. (2012). Factors contributing to students' poor performance in mathematics at Kenya Certificate of Secondary Education in Kenya: A case of Baringo County, Kenya. American International Journal of Contemporary Research, 2(6), 87-91. 